\title{
Assessment of Bacterial Water Load, Through Disinfection Processes, Chlorination and Ultraviolet
}

\author{
Cristina EL MAHDY ${ }^{1}$, Silvana POPESCU ${ }^{2}$, Blaga Petrean Anamaria ${ }^{2}$ and Cristin BORDA ${ }^{2}$ \\ ${ }^{1}$ Department of Fundamental sciences, Faculty of Animal Science and Biotechnologies, University of \\ Agricultural Sciences and Veterinary Medicine Cluj, România \\ ${ }^{2}$ Departament of Animal production and the food safety, Faculty of Veterinary Medicine, University of \\ Agricultural Sciences and Veterinary Medicine, Cluj, România \\ *Corresponding author, e-mail: silvana.popescu@usamvcluj.ro
}

Bulletin UASVM Animal Science and Biotechnologies 75(2)/ 2018

Print ISSN 1843-5262; Electronic ISSN 1843-536X

DOI:10.15835/buasvmcn-asb: 2018.0013

\begin{abstract}
The purpose of the research was to evaluate the degree of reduction of the bacterial load of water using as chemical disinfectant chloramine T 1\% (ChT1\%) and physical disinfection using UV at a wavelength of $253.93 \mu \mathrm{m}$, 30 minutes exposure time. The results of the research show a more significant reduction of TNG/ml of water in samples subjected to exposure to UV, but in this case the decrease is affected by the turbidity of the water.
\end{abstract}

Keywords: chlorination, TNG, turbidity, ultraviolet, water

\section{INTRODUCTION.}

Chloramine, secondary disinfectants, is recognized as a safe disinfectant and a good alternative to chlorine (https://www.cdc.gov/, 2015). Is a weaker disinfectant than free chlorine but, the residual chloramine is more stable and longer lasting so, it provides better protection against bacteria re-growth (Metzger, 2007) and does not produce carcinogenic trihalomethanesor haloacetic acids (Pedraza, 2015). UV treatment provides an excellent disinfection without generating byproducts, no introduction of disinfectant-resistance to bacteria (Songet al., 2016). UV light inactivates microorganisms by modifying their DNA, preventing replication or infection, and a sufficiently large dose may inactivate waterborne enteric pathogens (Oram, 2014).Ultraviolet disinfection is safe, it destroys the germs but the action is also dependent on the turbidity of the water (https://novascotia.ca/, 2017).

\section{MATERIALS AND METHODS}

The samples was collected from a local source of water permanently contaminated with organic matter (brook) located at latitude 46.747 and longitude 23.524. Water samples (10) taken under sterile conditions, were analyzed by point of view ofinitial bacterial load by mixing $1 \mathrm{ml}$ of water in Petri dishes to $18 \mathrm{ml}$ of agar which was incubated at $37^{\circ} \mathrm{Cfor} 24$ hours.Afterwards, was analyzed turbidity with portable turbidimeter ISO HI 98713, degree of contamination with organic matter.For water disinfection was used0.2-0.3 $\mathrm{ml}$ chloramine $\mathrm{T} 1 \%$ (ChT 1\%)and UV.From the raw water samples exposed to ultraviolet for 30 minutes and from samples in which ChT $1 \%$ is the disinfectant, were taken $1 \mathrm{ml}$ of water poured in Petri dish and mixed with $18 \mathrm{ml}$ agar incubated at $37^{\circ} \mathrm{C}$ for 24 hours. The statistical analysis was performed after a nonparametric testKruskalWallis, the results being represented asmean \pm SD, and the differences considered significant if $p$ $\leq 0.05$, using SPSS software. 
Table 1. NTG / $\mathrm{ml}$ water values for samples subjected to Chloramine T $1 \%$ and UV disinfection

\begin{tabular}{|c|c|c|c|c|c|c|c|}
\hline \multirow{2}{*}{$\mathrm{n}$} & \multirow{2}{*}{ Parameters } & \multirow{2}{*}{ Mean \pm sd } & \multirow{2}{*}{ Min } & \multirow{2}{*}{ Max } & \multirow{2}{*}{$\begin{array}{l}\text { RW-UV } \\
30 \mathrm{~min} .\end{array}$} & \multicolumn{2}{|c|}{ WChT1\% } \\
\hline & & & & & & $0.2 \mathrm{ml}$ & $0.3 \mathrm{ml}$ \\
\hline 10 & RW & $4060.70 \pm 3174.30$ & 1251.00 & 9920.00 & $* * *$ & ns & $*$ \\
\hline 10 & RW-UV & $104.30 \pm 103.89$ & 21.00 & 334.00 & - & & ns \\
\hline 10 & WChT1\% $0.2 \mathrm{ml}$ & $1199.50 \pm 581.87$ & 588.00 & 2065.00 & - & - & ns \\
\hline 10 & WChT1\% $0.3 \mathrm{ml}$ & $646.40 \pm 464.40$ & 263.00 & 1860.00 & - & - & - \\
\hline & & Reduction of NTG & & & $38.93 \mathrm{t}$ & $3.38 \mathrm{t}$ & $6.28 \mathrm{t}$ \\
\hline
\end{tabular}

Legend: Min- Minimum;Max - Maximum, min- minutes, RW-raw water, RW-UV- raw water-UV exposure, WChT1\% water subjected to disinfection to chloramine $\mathrm{T}$, $\mathrm{n}$ - No of samples, ${ }^{* * *}-\mathrm{P}<0.001$;

** $-\mathrm{P}<0.01,{ }^{*}$ - $\mathrm{P}<0.05$; ns- $\mathrm{P}>0.05$; t-time

\section{RESULTS AND DISCUSSION}

The turbidity of the raw water varied between 36 and 111 NTU ( $69.74 \pm 22.26)$, while, the organic matter: $3.83-16.22 \mathrm{mgO}_{2} / \mathrm{l}(8.60 \pm 4.59)$. Dependent on the disinfection method applied without any prior water treatment, it is noted that, the best option is water exposure to UV, the differences being extremely significant as TNG/ $\mathrm{ml}$ water, reduction between raw sample and this disinfection method. However, disinfection efficiency has been affected by high water turbidity. Suspended particles are a problem because, the microorganisms buried in theparticles, are protected and not destroyed (Dreeszen, 2003), and another cause would be that, UV dosewas not enough $\left(1 \mathrm{log}, 3.88 \mathrm{mj} / \mathrm{cm}^{2}\right)$ calculated by formula (Leinberger, http://www.elaguapotable.com/). Using ChT1\% as a disinfectant, the differences between the raw samples and those with the addition of $0.3 \mathrm{ml}$ of $\mathrm{ChT} 1 \%$ are significant as can be seen from the table (1) and insignificant at $0.2 \mathrm{ml}$. The residual chlorine is $0.5-0.7 \mathrm{ml} / \mathrm{l}$ for the use of $0.3 \mathrm{ml} \mathrm{ChT1 \%}$ and, $<0.3 \mathrm{ml} / \mathrm{l}$ at 0.2 $\%$ ChT1\%. A distinctly significant reduction of $\mathrm{TNG} / \mathrm{ml}$ water with $91.32 \%$, can be ascertained by using UV $(104.3 \pm 103.89)$ versus $0.2 \mathrm{ml}$ of ChT1\%(1199.5 \pm 581.87$)$. TNG/ml water from the samplewith ChT1\% 0.2 mlhas diminished of 3.38 times, 6.28 times in the sampleswith ChT $1 \% 0.3 \mathrm{ml}$ and, 38.93 times at exposure of raw water for 30 minutes at UV compared to the average obtained in the initial samples.One of the reasons why chlorination was not effectivecan be attributed to the large amount of organic matter, which after Küpperet et al., 2009 may have unfavorable influence on the disinfection process.

\section{CONCLUSION}

The most effective solution for disinfection without pre-treatment of water is UV, but, turbidity affects the effectiveness of disinfection

\section{REFERENCES}

1. Dreeszen, P. H. (2003).UVradiation. www.water-research. net/

2. Küpper, T.E.A.H., Schöffl,V.,Milledge, J.S (2009)Water disinfection in the mountains estate of the art recommendation paper of the Union Internationale des Associations d'Alpinisme Medical Commission, Travel Medicine and Infectious Disease vol. 7, 7-14

3. Leinberger J. Disinfection of Drinking Water with Ultraviolet Lighthttp://www.elaguapotable.com/

4. Metzger, M. (2007). The ABCs of Bacteria Removal, https://www.wqpmag.com/)

5. Oram, B. (2014). Drinking Water Treatment with UV Irradiation, https://www.water-research.net/

6. Pedraza, J.M. (2015). What is the best method for disinfection of water https://www.researchgate.net/

7. Song, K., Mohseni, M., Taghipour, F. (2016). Application of ultraviolet light-emitting diodes (UV-LEDs) for water disinfection: A review, Water Research 94: 341-349.

8. Disinfection with Chloramine https://www.cdc.gov/ healthywater/drinking/public/chloramine-disinfection. html, 2015

9. Ultraviolet Disinfection For Drinking Water https://novascotia.ca/nse/water/uvdisinfect.asp, Updated: 2017-Dec10 